\title{
AN EXAMPLE OF LYMPHOGRANULOMATOSIS COMBINING WITH LEPROSY
}

\author{
Shigenori Ishihara \\ National Suruga Sanatorium
}

1. I met with a very rare case in which lymphogranulomatosis combined with lepra nervosa at the autopsy of leprosy,

2. This disease not only systematically injured many lymph-glands, for example, cervical glands, mediastinal glands, abdominal glands, axillary glands, and inguinal glands, etc. but also gave changes to lungs, a spleen, kidneys, and pancrease, etc.

3. We generally fined in protein fraction of lepra nervosa that albumin and globulin is neary in-proportion. In this case, however, globulin, especially $r$ globulin increased to an exceptional degree. Therefore, it may be concidered that the increase of $r$ globulin was caused by Hodgkin's disease.

\section{癩に合併した淋巴肉芽腫症の 1 例}

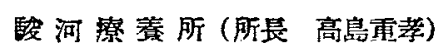

石原重德

\section{緒言}

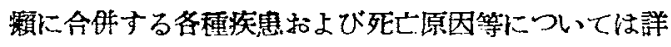

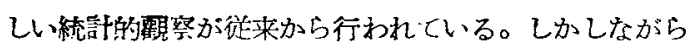

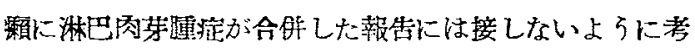

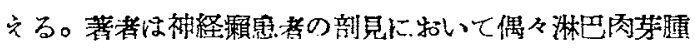

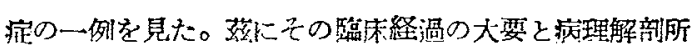
見の主要なる事項について報告する。

\section{臨床 經 過}

\section{蓄○忠○ 497 男}

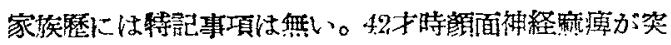

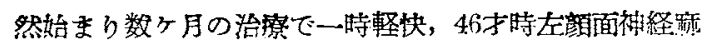

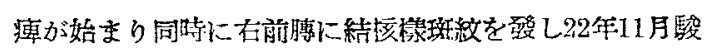
河㞠養所以入所す。

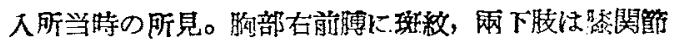

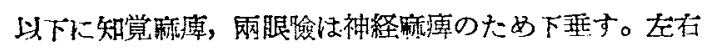

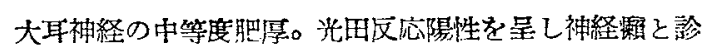
断さる。

入所後は大風子活注射の治撩を受けたが著変なく，血 尿のため診を受け㹂炎として治撩を受けた程度である
が，每月の赤沈は一時間梿何れる80〜110を前後してい

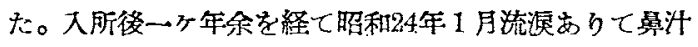

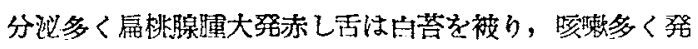

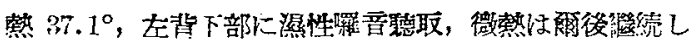
たが10日前啳で平熱となつた。その後時々気管支炎の症

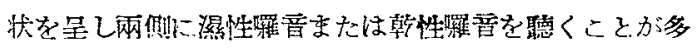
かつた。24年 8 月に胸痛めりて䛦を受けたがその際を项

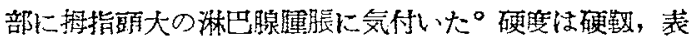

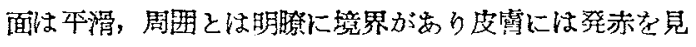

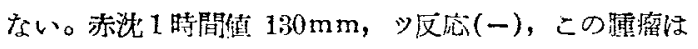
軟化しまたは大きくなることもなかつた。8月に撮影し た胸部名眿所見に物いては著しい所見を見ず，更にタ月 に胃部に不快感があり資血を認めたので琴のX楾検查を

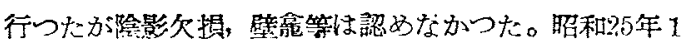

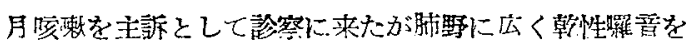

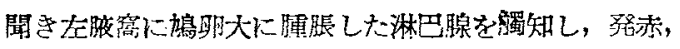

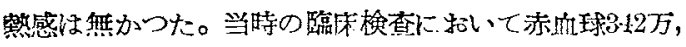

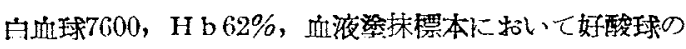
增加は見なかつた。血清の分港では $\mathrm{A}=40, \mathrm{G}=60, \alpha-$ $\mathrm{G}=20, \beta-\mathrm{G}=6, \gamma-\mathrm{G}=34, \mathrm{~T} . \mathrm{B}=8.2 \mathrm{~g} / \mathrm{dl}$ ，原所

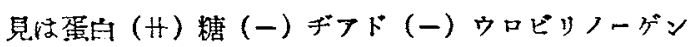


(十) 9区応 (-)

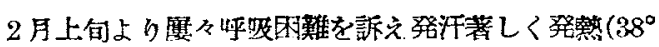
C $\left.239^{\circ} \mathrm{C}\right)$ を見ペニシリン注射等により 10 日前後で下 䓡する症状が数回あり5月まで続いた。5月になつて頸

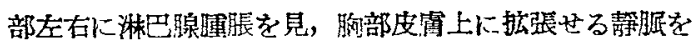
見た。 5 月9日の胸部X楾像に妨いて在者兩肺野全域に

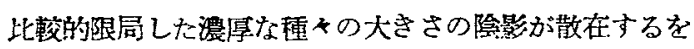
見，悪性隀湯の脑転移と考えた。5月中旬より連日呼吸

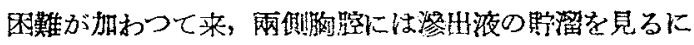
至り再三第針排除を行つたが，下抆顏面下浮腪が强くな り9月 4 日死亡した。

\section{解 剖 所 見}

\section{主要な剖唡所見を記迅すると次の通りである。}

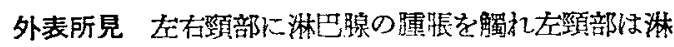
巴腺腫脹により肥大する。腋简（左）在层䠏鿟巴腺には 彩䀦大の淋巴腺睡脹むり。手指は兩手指共に强く屈曲す る。

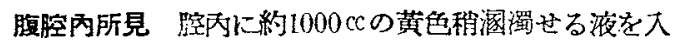

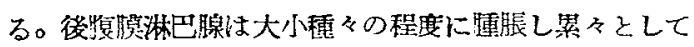

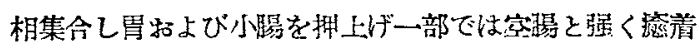
している。

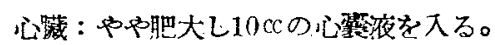

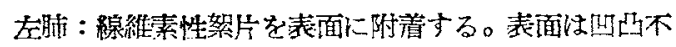
本で表面或は內部に大小不同，堆囲と明眿に㜔される硬

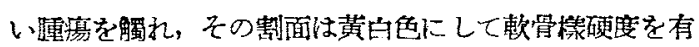
しておん，霓燙の間に介在する肺組織は血量にこしくそ

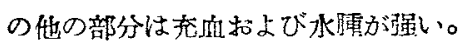

右肢：左㩆と殆ど同裳の所見。

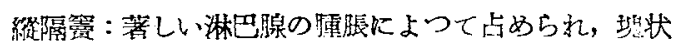

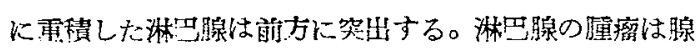

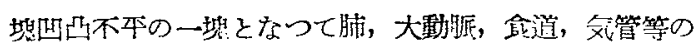

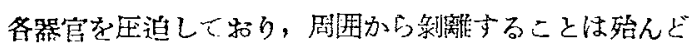

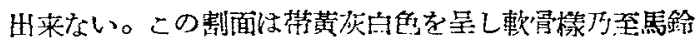
蕾を㽖る如き硬さである。

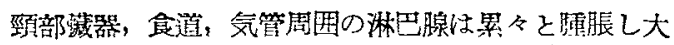

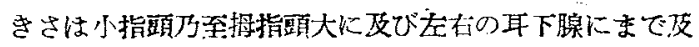
んでいる。

肝藏：大ささ稍小 $(907 \mathrm{~g} ， 26 \times I 6 \times ? .8)$ 質柔軟，小

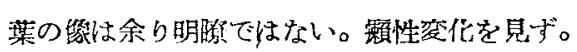

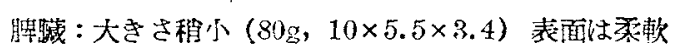
なるす外部より臅知与るに涪部に硬い球状のるのを触れ

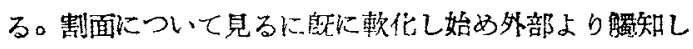

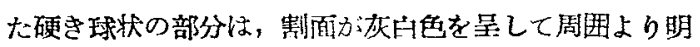

らかに区放されかなり著しく突出している。この灰白色 の割面に赤蝎色の地区状の模榜を見る。濾胞の発常は稍

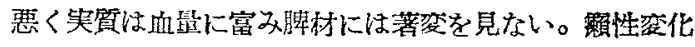
を見ない。

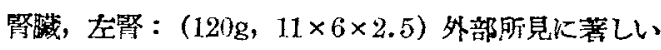

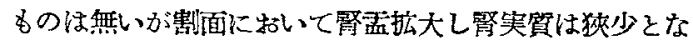
る。皮䯕の境界は既ね明嘹。

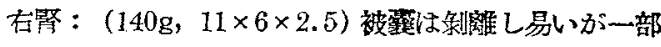
に稍制馓し歏き部分を見る。

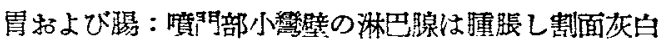

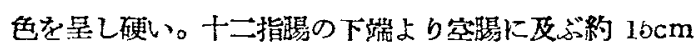

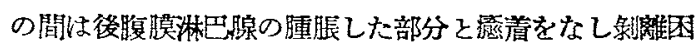
歏である。

後腹璄淋巴腺：腹部大動胝を中心として左有に，また 前面に向つて多数の糔巴腺か堙镸し累々と重なり合つて

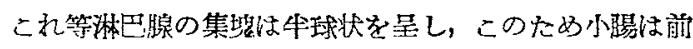

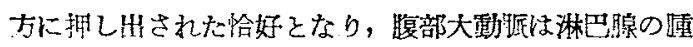

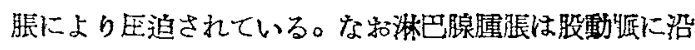
つてす認められた。

\section{病理組織學的所見}

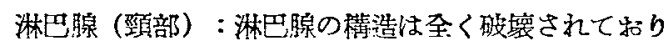

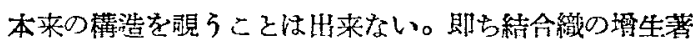
しく，淋巴球，形筫細胞の浸潤をその間に茄め，不正山 形乃至分葉状の根を有する単核または多数のステルンべ ルグ氏型の互細胞が多数に見られる。一部には偯死に陷 入り核の貱片を見る。好酸球は㒖に認められる。なお鼠

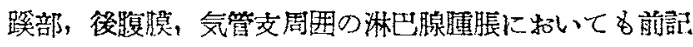

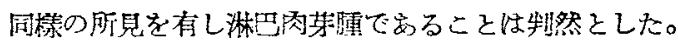

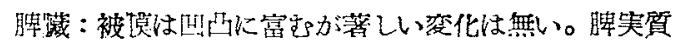

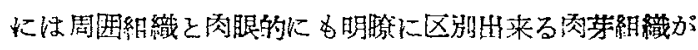
円形に認められる。この肉茅揞变化は結合織細胞の䞍殖 藷しく淋巴球，類上皮細胞，形望細物等上りなり，ステ

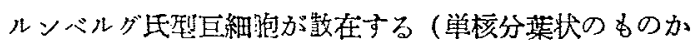
らら〜6偲の核を有するもの等種々岕り)。た所くには 装死に陷入り核の破片を多数に哂め的子樣变性の傾向を

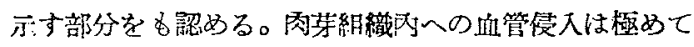
賀殿である。

晖の実筫はこの网芽組織の壻殖のため压排されて辆状

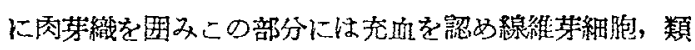
上皮細胞，秒質細胞等の浸潤が著しく僅少の好酸球，亘 細菢をむ混ずる。粠巴㴔胞は㱠んど制然せず，僅かに中

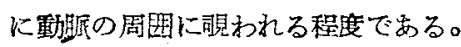

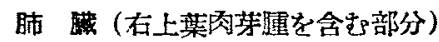




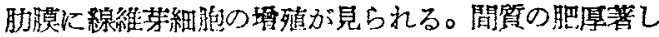

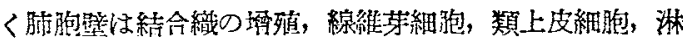

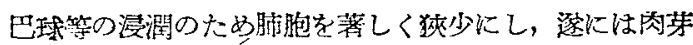
組織水てて充浾す。このために肺は网眼的にる明らかな輪 状の肉茅細織で占據されている。これらの网芽組織は上

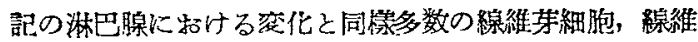
細胞，淋巴球，類上皮細胞等よりなりステルンペルグ氏

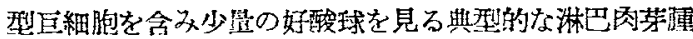
で女る。輸状汇形成された网菜揮の間に介在する肺胞內

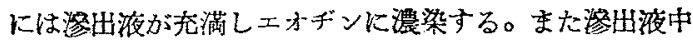
には多数の心藏病細胞を見る。肉芽腫のない部分に执い

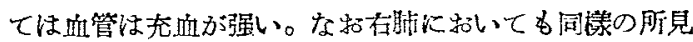
が㦘められる。

堅 (右婜)

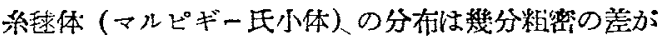
見られる。系球体は腫大し核の增殖を見るすのが多いが

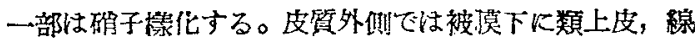
維特よび楾維芽細胞，淋巴球，形質細胞の浸潤を主とし て見，中に雚少の巨細胞を混した肉芽組織が間質に沿つ

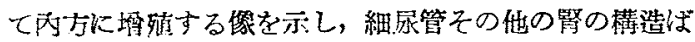
肉芽組織仗置換えられて抢りまたは萎縮している。皮貿

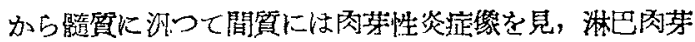
睡症の比較的早期と考穴られる。

左蜸

右掔よりは軽度であるが相似た没化を認める。 心および心覀

心藏には心筫の萎縮と褐色々素の沈着を見る外，間留 には類上皮，椙維緗胞等よりなる浸潤を認める。また心

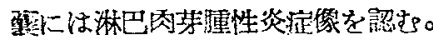

肝

䀒細咆の萎縮に上り細狍索は猍くなり核を中心た褐色 々素の沈着等の裸色萎樎化を示寸。しかしながら淋巴肉 芽揰症性变化は見ない。

\section{膵瞙および腹部淋巴腺}

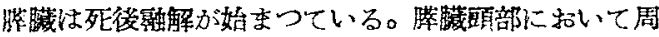

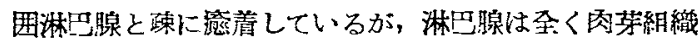
に変りホヂキン氏病の像か萻明である。この肉芽性炎は

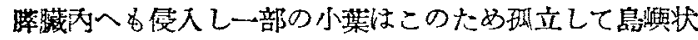
そなり或えすの慣死に陷入る。

腸 菅 (空踢扣よび迴腸)

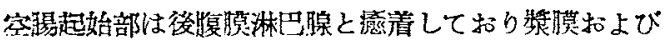

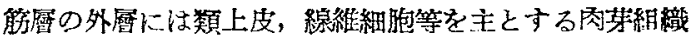

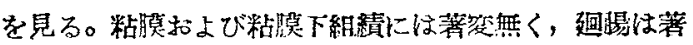
しい变化を見ない。

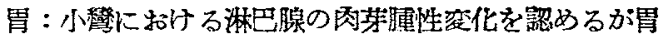
自体の袈代はない。

その他の欌器：甲状腺，香，亘造，㣂倔，睪丸等飞著 方を見ない。

\section{總括及び考按}

以上記した如く本例は神経澒に合併した淋巴肉芽楎症

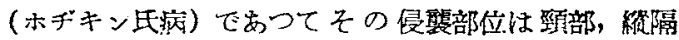

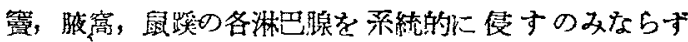

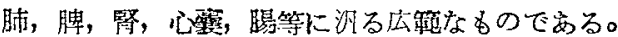

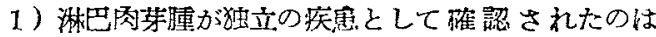
Sternberg（1898）以後であるがその原因については結 核菌 (Sternberg) 牛型結核菌 (Sticker, Löwenstein 频尾）等があげられているが確認されてはいない。本例

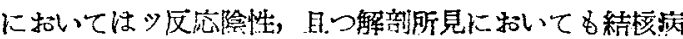
笱は認めなかつた。

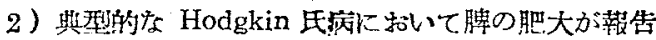
されているが本例は85gで大きさも尋常以下である。ま

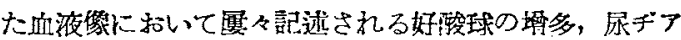
ゾ反㐫陽性も本例にては見ることが出来なかつた。しか しながら本例はその組樴像においては典型的な淋巴腐芽

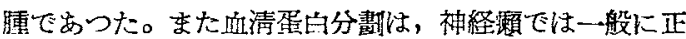
常人之殆んど大差ないが本例は上述の如くグロブリン增 加，珠に 覧泟のためと考えられる。

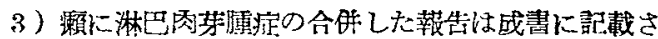
れたことを知らないし，光田缐長からす「多数の剖検例 に扎て確実にホデキン氏病とい方例は知らぬ」由を

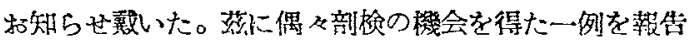
する次第である。

(本研究に学つて高烏所長, 震応大学青木敏授から多 くの御敎示を戴いた。ここに御䄈申乙上げる)

\section{文献}

Klingmüller : Handbuch d. Haut. u. Geschlechts Krankheiten X-2 (Lepra)

Aschoff : Pathologische Anatomie Band I u I (1 986)

Borst : Pathologische Histologie (1922)

Rogers and Muir : Leprosy

今 㭲 : 近世崔理解剖学

緒方知三郎：病理解部学総論

禾村 男也：小病理学総碖 


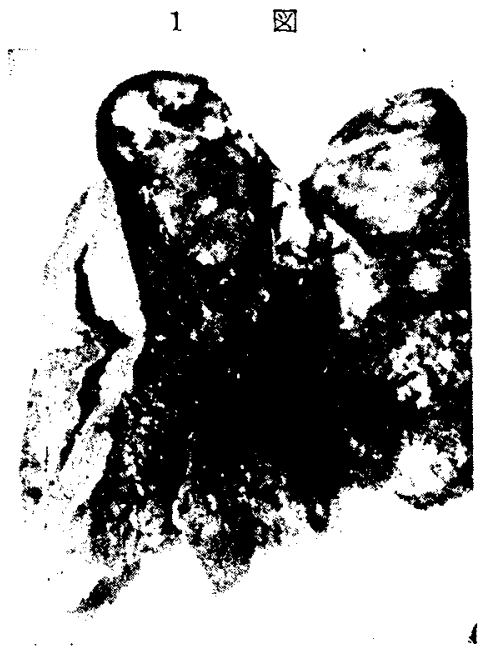

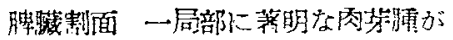

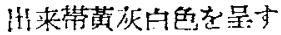

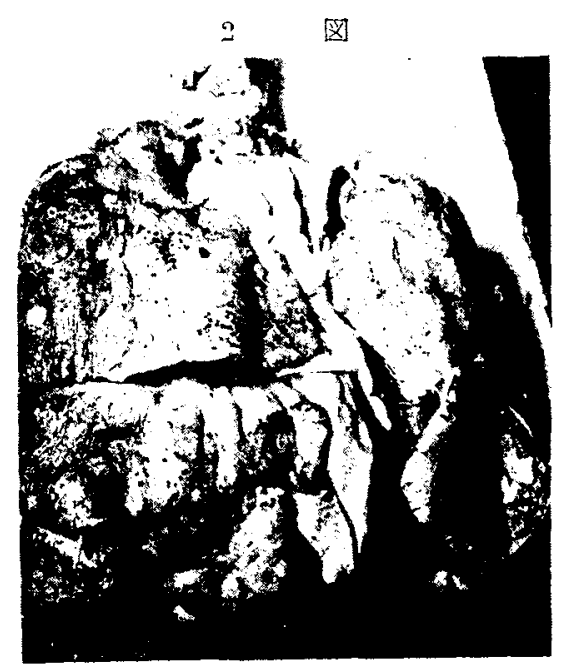

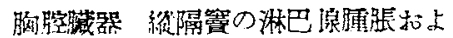

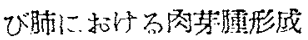

\section{8 図}
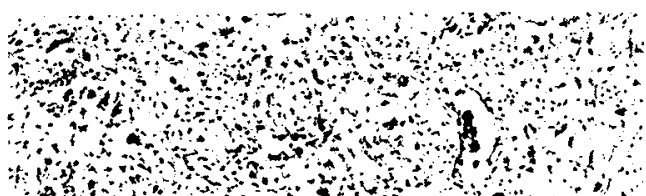

in

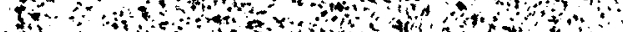

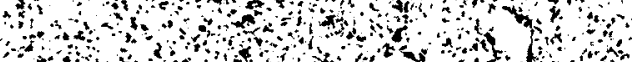

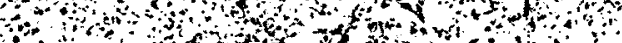

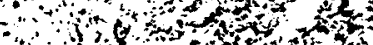

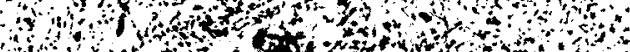

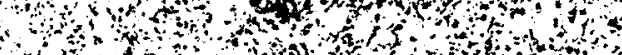
1)

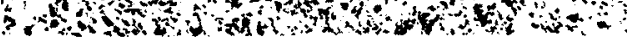
淋巴腺（频部）所々心宣細跑州現し，結合 線維の埼愐著しく，淋巴球，形所細胞，類上 皮細胞の浸澗著しい。(H-E染保)

$$
5 \text { 圆 }
$$

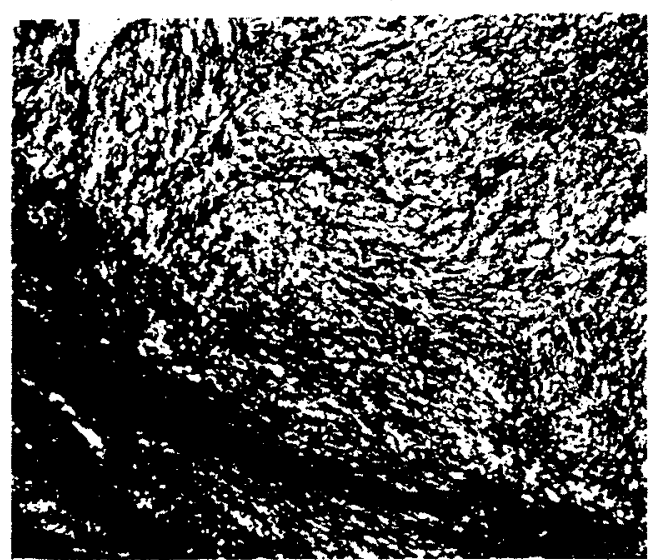

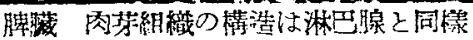
ステルンベルグ氏互細胞を混ずる。

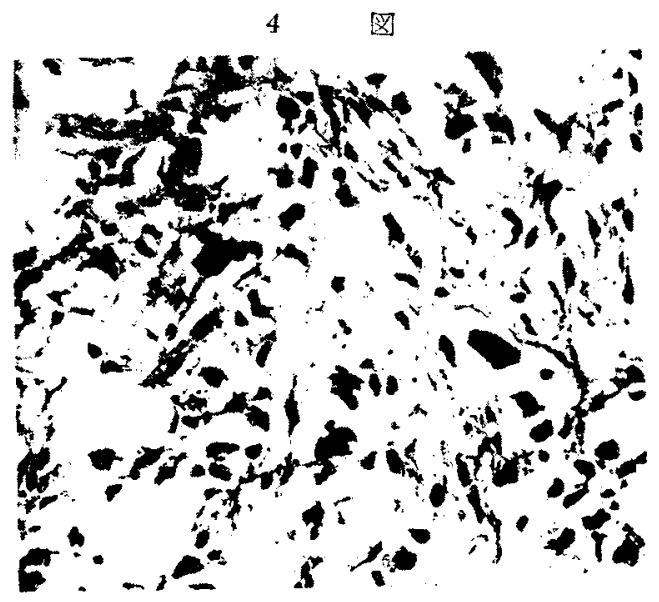

前記强抬大 $(\mathrm{H}-\mathrm{E}$ 㜣色)

\section{6 㘣}

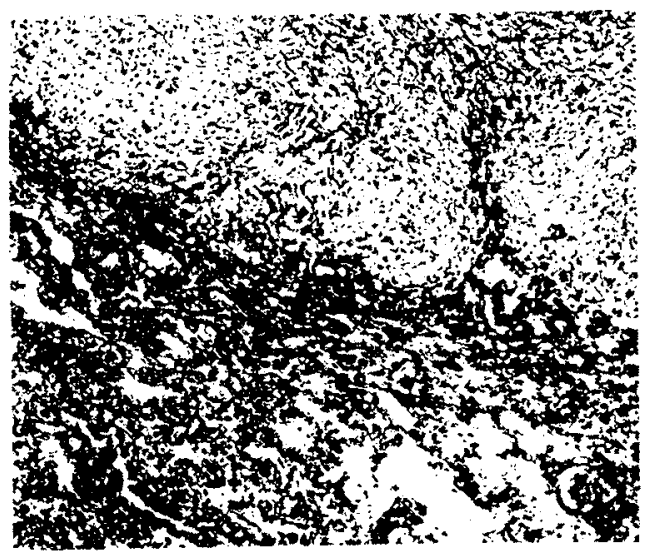

肺藏质芽縕織の形成，蹨接肺 組織は压排さる。 